\title{
The Role Of Product Quality Information, Market State Information And Transaction Costs In Electronic Auctions
}

\author{
Otto Koppius and Eric van Heck
}

\begin{tabular}{|l|l|}
\hline \multicolumn{2}{|l|}{ ERIM REPORT SERIES RESEARCH IN MANAGEMENT } \\
\hline ERIM Report Series reference number & ERS-2002-73-LIS \\
\hline Publication & August 2002 \\
\hline Number of pages & 25 \\
\hline Email address corresponding author & O.Koppius@fbk.eur.nl \\
\hline Address & Erasmus Research Institute of Management (ERIM) \\
& Rotterdam School of Management / Faculteit Bedrijfskunde \\
& Erasmus Universiteit Rotterdam \\
& P.O. Box 1738 \\
& 3000 DR Rotterdam, The Netherlands \\
& Phone: +31 104081182 \\
& Fax: $\quad+31104089640$ \\
& Email: info@erim.eur.nl \\
& Internet: $\quad$ www.erim.eur.nl \\
\hline
\end{tabular}

Bibliographic data and classifications of all the ERIM reports are also available on the ERIM website: www.erim.eur.nl 


\title{
ERASMUS RESEARCH INSTITUTE OF MANAGEMENT
}

\author{
REPORT SERIES \\ RESEARCH IN MANAGEMENT
}

\begin{tabular}{|c|c|c|}
\hline \multicolumn{3}{|c|}{ BIBLIOGRAPHIC DATA AND CLASSIFICATIONS } \\
\hline Abstract & \multicolumn{2}{|c|}{$\begin{array}{l}\text { Electronic auctions have rapidly increased in popularity, but the consequences of switching to an } \\
\text { electronic auction are unclear. In part this is because multiple changes occur at the same time } \\
\text { so one can only observe the combined effect of these changes and not the effect of each } \\
\text { separate change. For instance, electronic bidders face lower transaction costs, but also have } \\
\text { less information about product quality and about the state of the market such as the number of } \\
\text { bidders. In this paper, we report a study of bidding behavior at a large Dutch flower auction in } \\
\text { which we are able to separate some of these effects. We compare electronic bidders with } \\
\text { traditional bidders and when correcting for quality differences and seasonal effects, we find that } \\
\text { they to bid lower on average than traditional buyers, as predicted by Bakos (1991, 1997). The } \\
\text { electronic bidders were divided in two subgroups, internal bidders and external bidders. The } \\
\text { external bidders had less product quality information and market state information than the } \\
\text { internal bidders. This led the external bidders to not only bid significantly higher than the internal } \\
\text { bidders, but in fact as high as the traditional bidders. Both these effects run counter to theoretical } \\
\text { predictions and some possible alternative explanations are offered. In general, it highlights the } \\
\text { importance of focusing the information flows that occur in a market. }\end{array}$} \\
\hline \multirow{3}{*}{$\begin{array}{l}\text { Library of Congress } \\
\text { Classification } \\
\text { (LCC) }\end{array}$} & $5001-6182$ & Business \\
\hline & 5201-5982 & Business Science \\
\hline & HF 5476 & Auctions \\
\hline \multirow{4}{*}{$\begin{array}{l}\text { Journal of Economic } \\
\text { Literature } \\
\text { (JEL) }\end{array}$} & M & Business Administration and Business Economics \\
\hline & M 11 & Production Management \\
\hline & R 4 & Transportation Systems \\
\hline & D 4 & Market Structure and Pricing \\
\hline \multirow{4}{*}{$\begin{array}{l}\text { European Business Schools } \\
\text { Library Group } \\
\text { (EBSLG) }\end{array}$} & $85 \mathrm{~A}$ & Business General \\
\hline & $260 \mathrm{~K}$ & Logistics \\
\hline & $240 \mathrm{~B}$ & Information Systems Management \\
\hline & $160 \mathrm{~B}$ & Price theory \\
\hline \multicolumn{3}{|c|}{ Gemeenschappelijke Onderwerpsontsluiting (GOO) } \\
\hline \multirow[t]{4}{*}{ Classification GOO } & 85.00 & Bedrijfskunde, Organisatiekunde: algemeen \\
\hline & 85.34 & Logistiek management \\
\hline & 85.20 & Bestuurlijke informatie, informatieverzorging \\
\hline & 83.80 & Industriële organisatie \\
\hline \multirow[t]{3}{*}{ Keywords GOO } & \multicolumn{2}{|c|}{ Bedrijfskunde / Bedrijfseconomie } \\
\hline & \multicolumn{2}{|c|}{ Bedrijfsprocessen, logistiek, management informatiesystemen } \\
\hline & \multicolumn{2}{|c|}{ Veilingen, Internet, Markt, Informatie, Productinformatie, Transactiekosten } \\
\hline Free keywords & \multicolumn{2}{|c|}{ electronic auctions, market state information, product quality information, transaction costs } \\
\hline
\end{tabular}




\title{
The role of product quality information, market state information and transaction costs in electronic auctions
}

\author{
Otto Koppius and Eric van Heck \\ Dept. of Decision and Information Sciences (F1-31) \\ Rotterdam School of Management \\ Erasmus University Rotterdam \\ PO Box 1738 \\ 3000 DR Rotterdam \\ The Netherlands \\ $\mathrm{T}:+31.10 .408 .2032$ \\ F: +31.10 .408 .9010$ \\ E: O.Koppius@fbk.eur.nl
}

Version: January 2002

Presented the Academy of Management 2002, TIM division

Abridged version published in the Best Paper Proceedings

Note: this is a working paper and may therefore undergo significant changes until the final version appears in print. Feel free to cite this paper, but please check with the authors that you have the most recent version before citing it. Feedback is always appreciated. 


\title{
The role of product quality information, market state information and transaction costs in electronic auctions
}

\begin{abstract}
Electronic auctions have rapidly increased in popularity, but the consequences of switching to an electronic auction are unclear. In part this is because multiple changes occur at the same time so one can only observe the combined effect of these changes and not the effect of each separate change. For instance, electronic bidders face lower transaction costs, but also have less information about product quality and about the state of the market such as the number of bidders. In this paper, we report a study of bidding behavior at a large Dutch flower auction in which we are able to separate some of these effects. We compare electronic bidders with traditional bidders and when correcting for quality differences and seasonal effects, we find that they to bid lower on average than traditional buyers, as predicted by Bakos $(1991,1997)$. The electronic bidders were divided in two subgroups, internal bidders and external bidders. The external bidders had less product quality information and market state information than the internal bidders. This led the external bidders to not only bid significantly higher than the internal bidders, but in fact as high as the traditional bidders. Both these effects run counter to theoretical predictions and some possible alternative explanations are offered. In general, it highlights the importance of focusing the information flows that occur in a market.
\end{abstract}

Keywords: electronic auctions, market state information, product quality information, transaction costs 


\section{Introduction}

An auction is a market institution with an explicit set of rules determining resource allocation and prices on the basis of bids from participants (McAfee \& McMillan 1987). One necessary condition for an auction to be practical is that there uncertainty over the value of the object being auctioned; otherwise the seller could simply set a fixed price instead. Resolving this uncertainty by letting auction participants bid for the object is an attractive option, but it also entails costs for setting up the auction and for buyers and sellers to gather in one place, i.e. transaction costs (Coase 1937). This means that another necessary condition for an auction to be practical is that the transaction costs for buyer and seller are small enough compared to the additional benefit they get from holding an auction instead of setting a fixed price. Traditionally, this meant that auctions were used primarily for high-value items such as paintings and construction projects or in cases where there are large fluctuations in supply and/or demand, such as flowers, fish and other agricultural products. In the high-value-items case the potential extra gains for the seller of finding a bidder who is willing to pay a high price outweigh the seller's transaction costs and the high value to the buyer outweighs his transaction costs. In the supply/demand-fluctuations case the transaction costs for a single, isolated auction would be too large compared to the modest value of agricultural products, but holding many auctions in a short period of time lowers the transaction costs for buyers enough to make participation feasible.

Enter the Internet. With its open standards, relatively low entry barriers and low cost of communication, the Internet makes gathering people in one place a lot cheaper. Instead of having to physically gather in one place to bid, bidders can now gather electronically via newsgroups, email lists and webpages. Electronic bidding removes a large part of the transaction costs associated with traditional auctions and as a consequence, auctions have sprung up everywhere. The posterchild of electronic auctions is eBay, which now has nearly 40 million registered users, hosts over 3 million auctions each day and the total value of goods traded through eBay approached 10 billion in 2001 (www.ebay.com). While eBay focuses particularly on the consumer market (consumer-to-consumer (C2C) and business-toconsumer (B2C)), in the last two years the business-to-business (B2B) market has grown 
significantly and is now dwarfing the consumer market in size. Companies such as FreeMarkets, e-Steel, ChemConnect, VerticalNet, FastParts and numerous others have set up auctions aimed at improving the purchasing processes in the supply chain. Although such ventures are receiving a lot of enthusiasm in the business press (and for a while on the stock market as well), it is an open question what auction models will be successful in the long run, because the consequences for the various stakeholders involved of using electronic auctions are unclear. A first step towards progress on these issues can be made by looking in more detail at the differences between a traditional auction and an electronic one.

A move from traditional trading to an electronic auction entails several changes. One such change is in the product representation, in other words how product quality information is made available through ICT. Previous research (Koppius, van Heck \& Wolters, 1998, forthcoming) showed that a reduction in product quality information led to bidders lowering their bid to compensate for the increased quality uncertainty online. This paper deals with a second change, namely the fact that buyers no longer have to physically gather in one place to bid like in a traditional auction. This physical gathering can be very cumbersome and leads to high transaction costs because the buyers have to incur extra time and travel costs to get to the auction hall. One strategy that auction houses use to reduce transaction costs is to allow mailin bids or phone bids: with mail-in bids, bidders can privately announce their highest bid (i.e. their willingness-to-pay) to the auctioneer before the auction, who then conducts the auction as if the bidder were present in the room. In the case of phone bids, bidders can also stay on the phone with the auction hall during the auction. That way they can bid just as if they were physically there, except for the fact that they cannot see the actual product and the other bidders. Both mail-in and phone bidding reduce the transaction costs of the auction for such bidders.

Essentially, electronic bidding through new ICT forms such as the Web and email are new variants on the phone bidding principle. However, an added advantage of electronic bidding is that it is cheaper than phone bidding and perhaps more importantly, the information disadvantage of phone bidding can be countered to some extent through electronic product 
representation, although nullifying this information disadvantage is by no means easy (Koppius, van Heck \& Wolters 1998, forthcoming). One aspect of phone, mail or electronic bidders remains though: such bidders do have an information disadvantage compared to the bidders in the auction hall. For instance, they cannot see how many bidders there are, they cannot see if specific bidders are present or not and they cannot hear the level of excitement or 'buzz' (Coval \& Shumway 2000) of the auction. These types of information belong to what more generally can be called market state information, which can be defined as public, nontransaction signals that influence trader behavior and such information can have a significant impact on market processes (Coval \& Shumway 2000). The literature on electronic markets to date has particularly investigated the consequences of lower transaction costs (Bakos 1997), but the discussion above suggests that the changes in market state information available to traders in electronic markets compared to traditional markets should be taken into account as well.

These two aspects will be investigates in this paper in a study of an ICT initiative called KOA ('Kopen Op Afstand', which means 'Buying From A Distance') at a large Dutch flower auction. In the KOA system, bidders had the option to bid from their offices, using special software and an ISDN linkup to the computer in the auction hall. These electronic bidders, or KOA-bidders, participated in the exact same auctions that the bidders in the auction hall itself were bidding on, so electronic bidders and physical bidders were competing against each other. This allows a direct comparison between electronic bidding behavior and traditional bidding behavior. The next paragraph describes the theoretical background regarding the differences between traditional and electronic bidding behavior. Paragraph 3 describes the KOA initiative. Paragraph 4 provides the data, model and methodology. Paragraph 5 describes the results of the statistical analysis, which are discussed in paragraph 6 and paragraph 7 concludes. 


\section{Theoretical background}

The literature on electronic markets has its roots in the seminal work of Malone, Yates \& Benjamin (1987) who discuss how ICT influences the choice of coordination mechanism, i.e. the electronic markets vs. electronic hierarchies debate. One of the factors influencing the choice of coordination mechanism in their analysis is the complexity of product description and they argued that databases and high-bandwidth electronic communication enable markets to effectively communicate more complex product descriptions than before, leading to lower transaction costs in electronic markets.

Transaction costs were further investigated in Bakos (1991, 1997), who emphasized the reduced search costs for buyers in an electronic market. The most important implications of this search cost reduction were an improved allocative efficiency as buyers now can find sellers that better match their needs and a reduction in prices paid, due to increased competition between sellers. This 'reduced price hypothesis' has found mixed empirical support. Lee (1998) investigated the case of Aucnet, an electronic auction for second-hand cars in Japan and found that prices in the Aucnet auction were significantly higher than the traditional car auctions and offered several explanations for this phenomenon. The most important explanation is that because Aucnet screened out the low-quality cars (i.e. the 'lemons', Akerlof (1970)) through their quality rating system, their cars were on average of higher quality than the traditional car auctions. Subsequent analysis (Lee, Westland \& Hong 1999) showed that correcting for the quality difference did decrease the price difference, but did not eliminate it. Thus other factors have to be taken into account to explain the price difference. One of these is again related to Aucnet's quality rating system: besides screening out the lemons, the general thoroughness of Aucnet's car inspection process increased the trust that bidders had in the quality of the cars being auctioned, which leads to higher prices (see also Lee \& Clark (1997)). Another factor is that the electronic representation of the cars made it attractive for sellers to sell their cars through Aucnet so they could avoid the high transportation and parking costs of physical auctions. This wider assortment attracted more buyers and this buyer externality leads to higher prices, which in turn again attracts more sellers and so on. A final factor may be that it is the premium that buyers are willing to pay 
for not having to physically travel to an auction and for having a higher chance of finding a vehicle that best matches their preferences.

Bailey (1998) also found higher prices online when he compared prices for books, CDs and software online and offline, as well as larger price dispersion online. These findings were particularly surprising as these categories are considered to be homogeneous goods, for which the reduced price effects theoretically should be most forceful (Bakos 1997). A likely explanation for this was the immature state of electronic commerce at the time of data collection (early 1997). Around that time, competition among Internet retailers was not very strong because few retailers were active on the Internet and the average Internet user had an above-average income and therefore may have been less price-sensitive (Bailey 1998), which would enable retailers to sustain higher prices. Other potential explanations are high search costs on the Internet due to information overload and the possibility of price discrimination by retailers.

In a follow-up study on books and CDs, Brynjolfsson \& Smith (2000) improved Bailey's data collection methodology in order to arrive at a more accurate price comparison. They do find the predicted lower prices on the Internet (8-15\% difference) and also much smaller price adjustments by Internet retailers, both of which are indications of a more efficiently functioning market. However, they still replicate Bailey's (1998) finding of substantial price dispersion online, even larger price dispersion online than among conventional retailers, which again runs counter to the hypothesis of an efficient market (in the case of homogeneous goods). They note that models of search costs or asymmetric information cannot explain this finding and suggest that heterogeneity among retailers, particularly on issues related to trust and branding, could account for the observed price dispersion (Brynjolfsson \& Smith 2000). Other possible explanations are price discrimination (Clemons, Hann \& Hitt 2000), switching costs (Chen \& Hitt 2000) and convenience and awareness (Smith, Bailey \& Brynjolfsson 1999).

Degeratu, Rangaswamy \& Wu (2000) took a different approach when they compared shopping behavior in a traditional supermarket with shopping behavior at Peapod, an online 
supermarket. They distinguished four categories of search attributes of a product: brand name, price, sensory attributes (product attributes that can be determined through the senses), and non-sensory attributes (product attributes that can be described accurately in words). Focusing on consumer choice behavior and using information integration theory, they found that sensory attributes have lower impact on choices online, whereas non-sensory attributes have higher impact. Brand name also has a higher impact on online choice, but only if there is less attribute information available online than offline. Online consumers are more sensitive to price, but this is mainly due to the strong effect of online promotions. Once this is taken into account, online consumers are less price-sensitive than offline consumers.

Lynch \& Ariely (2000) also investigated the price-sensitivity of online consumers in relation to the search process. In an experimental environment of two competing online wine stores, they manipulated the search costs for price information and for quality information, as well as the ease of cross-store comparison. Easier cross-store comparison increased price-sensitivity (but only if both stores carried the wine that was searched for), but the search costs for price information had no consistent effect. They also found that a lower cost of obtaining quality information led to a decrease in price-sensitivity. Although the relationship between pricesensitivity and the magnitude of the search costs is dependent on the product being sold, their results do suggest that all three types of search costs need to be taken into account, as there is a tradeoff between them. More generally, this implies that comparison-shopping (as enabled by software agents or other intermediaries) does not inevitably lead to an all-out price war as predicted by some (Sinha 2000) when the quality information of differentiated products is readily available.

\section{The Dutch flower auctions and the KOA initiative}

Dutch flower auctions use a clock for price discovery as follows. The computerized auction clock in the room provides the buyers with product characteristics such as stemlength or diameter or number of leaves (dependent on the particular flower type), as well as information on the producer, unit of currency, quality and minimum purchase quantity. The flowers are 
transported in different lots (the flowers in each lot have identical characteristics) through the front of the auction room, where there is a person (the 'raiser') who shows the flower to the more than hundred buyers in the stand. The clock hand starts at a high price determined by the auctioneer, and drops until a buyer stops the clock by pushing a button. The auctioneer asks the buyer by intercom how many units of the lot he or she will buy. The buyer provides the number of units. The clock is then reset and the process begins for the remaining flowers, sometimes introducing a new minimum purchase quantity, until all units of the lot are sold and the auction starts for the next lot. In practice, it turns out that the Dutch flower auction is an extremely time-efficient auction mechanism: it handles one transaction every four seconds on average.

Traditionally, bidders have to be physically present in the auction hall in order to bid. The KOA initiative started as a pilot-project with electronic bidding. Initially it was offered to a few large buyers, who were expected to be the most likely early adopters for two reasons. One reason was that the KOA system required a significant investment in hardware and software: a dedicated computer, a double ISDN line to the auction hall as well as monthly fees to use system. The other reason was that the auction expected that buyers would be able to save on purchasing personnel costs, as the KOA system allowed buyers to efficiently monitor all the 13 auction clocks that run in parallel. Traditionally, large buyers needed to have several buyers present, one or more in each of the five auction halls to be able to do this monitoring efficiently. One of the expectations of the KOA system was that buyers would be able to do the same purchasing with one or two less purchasing personnel, which would offset the costs of the system. Interviews with KOA buyers indicated that such cost reductions did indeed occur.

In the KOA system, buyers did not see the actual flower (or a generic picture), but otherwise they did see the same information they would see if they were in the auction hall, i.e. information about upcoming auctions, minimum lot size, the supplier and various lot characteristics. They had a picture of the auction clock on their screen that was synchronized with the auction clock in the auction hall. Bidding was done by pressing the space bar. 
The KOA system quickly became a success as the benefits became obvious: several of the buyers saved significantly on personnel costs and all buyers were enthusiastic about the fact that they did not need to travel to the auction at early in the morning (auctioning starts at 6am). Another frequently mentioned benefits was the increased market monitoring capabilities that the system offered, not just for this particular flower auction, but also in combination with a similar KOA-type system from a large rival auction. The rollout of the system was subsequently expanded to mid-size buyers as well.

Not all KOA-users were alike though: several buyers (particularly the larger ones) had an office on the auction complex itself, in addition to their regular office. These internal buyers could also use the KOA system from those offices. This meant that they had the option, like the traditional buyers, to walk through the flower warehouse in the morning and physically judge the quality of the flowers and then return to their (internal) office to bid through KOA. In those internal offices they also had access to the security camera system, which enabled them to monitor activity in the auction hall. This way they could for instance see what had happened if there was a disruption in the auction process, but also they could see the number of bidders present in the auction hall. The external KOA buyers did not have this market state information as they did not have an office on the auction complex. To account for this difference we will distinguish between internal and external KOA buyers in the analysis in the next paragraphs.

Summarizing, KOA buyers had lower transaction costs compared to their traditional counterparts, but within the group of KOA-buyers, the external buyers had lower transaction costs than the internal buyers. With respect to the availability of market state information, the situation is reversed: traditional buyers have the most market state information, followed by the internal buyers and then the external buyers. The tradeoff between these two effects will be analyzed in the next paragraph.

In principle there is another change for the KOA-buyers compared to the traditional buyers and that is the electronic product representation as opposed to the physical showing of the flower by the raiser. As Koppius et al. (1998, forthcoming) showed in their analysis of screen 
auctioning for the flower type Anthurium at the same flower auction, switching to electronic product representation reduced the product quality information available to bidders, which caused a price drop. Screen auctioning was introduced a year before the KOA initiative, so for Anthuriums the traditional buyers in the auction hall did not have the advantage of seeing the physical product during the auction itself. They still had the option of going into the warehouse before the auction started to inspect the flowers, but so had the internal KOA buyers. As we focus on the Anthurium type in this analysis, the product representation effect plays no role here when comparing traditional and internal KOA-buyers (for external KOAbuyers it could still play a role as they could not go into the warehouse in the morning). This is an important methodological point, because previous studies of electronic markets could not distinguish between these two effects, since the effect of reduced product quality information on one hand occurred at the same time as the effect of lower transaction costs and reduced market state information on the other hand. In this study they can be separated.

\section{Data description and methodology}

To investigate the impact of KOA, we will look at bidding behavior for the flower type Anthurium. We will construct a regression model that predicts the price of an Anthurium with the type of buyer (traditional, internal KOA or external KOA) as a specific explanatory variable. The model will be tested on the auction transaction database, using data from the year 1997 and 1998. In this database for every transaction various data are kept, including data related to the seller, the buyer, the product (flower type, quality, stemlength and diameter etc.), and the transaction itself (price, quantity, date).

Discussions with flower auction employees revealed several factors that influence the Anthurium price that were use as control variables in the model. For Anthuriums, diameter of the flower (DIAM) is an important descriptive characteristic. The day of the week (WKDAY) influences price as well because different days of the week have structurally different supply and demand characteristics. Similarly, the trade of Anthuriums (and flowers in general) is highly seasonally dependent. Therefore, we corrected for this seasonal effect in the regression 
by including the average Anthurium price at all other flower auctions in Holland (VBN) as an extra variable. The quantity of the transaction (QUANT) is taken into account because bidders are expected to bid differently for large or small quantities. For each of the 9 flower subtypes in the database, we added a dummy variable FLWTYPE $\mathrm{F}_{\mathrm{i}}$ to account for the different prices that different subtypes fetch. KOA was introduced in early 1997, with a second rollout phase in the summer of 1997. This resulted in the following model (1):

PRICE $=\alpha+\beta_{1} *$ DIAM $+\beta_{2} *$ WKDAY $+\beta_{3} *$ VBN $+\beta_{4} *$ QUANT $+\beta_{5, i} *$ FLWTYPE $_{i}+$ $\beta_{6} * \mathrm{KOA}+\varepsilon .(1)$

Comparing KOA-buyers as a group with traditional buyers, so not distinguishing between internal and external KOA-buyers, the main differences are the lower transaction costs and the reduced market state information for the KOA-buyers. How and how strong the latter factor will influence bidding behavior is initially unclear, so the main factor is presumed to the lower transaction costs and we will first test the following hypothesis based on Bakos (1991, 1997):

Hypothesis 1: KOA buyers will bid less than traditional buyers, i.e. $\beta_{6}<0$.

We then constructed a second model (2) in which the KOA dummy was replaced by two dummies KOAEXT and KOAINT, to indicate if the buyer was an external KOA buyer or an internal KOA buyer. If both dummies were zero, the buyer was a traditional buyer in the auction hall. So in this analysis there were three groups of buyers.

PRICE $=\alpha+\beta_{1} *$ DIAM $+\beta_{2} *$ WKDAY $+\beta_{3} *$ VBN $+\beta_{4} *$ QUANT $+\beta_{5, i} *$ FLWTYPE $_{i}+$ $\beta_{6} * \mathrm{KOAINT}+\beta_{7} * \mathrm{KOAEXT}+\varepsilon$.

External KOA-buyers faced lower transaction costs, less product quality information and less market state information than traditional buyers. Internal KOA buyers had the same product quality information as traditional buyers, but their disadvantage regarding market state 
information (compared to traditional buyers) was less than the external KOA-buyers and they still had lower transaction costs than traditional buyers, so both types of KOA-buyers would still be expected to bid lower than traditional buyers. However, because internal KOA-buyers potentially had more product quality information at their disposal (if they chose to go into the warehouse), they could be expected to discount less for product quality uncertainty and therefore bid higher than external KOA buyers. As in the previous hypothesis, the direction and size of the effect of reduced market state information is not specified and the main factor are presumed to be the transaction costs and product quality information. In short, we will test the following hypotheses:

Hypothesis 2a: Both internal and external KOA buyers will bid less than traditional buyers, i.e. $\beta_{6}<0$ and $\beta_{7}<0$.

Hypothesis $2 b$ : Internal KOA buyers will bid more than external KOA buyers, i.e. $\beta_{6}>\beta_{7}$.

\section{Results}

The two models above were tested on 81,803 transactions for Anthuriums using sequential OLS regression with two blocks of variables. The first block contained all the control variables: VBN-price, diameter, length, quantity and dummies for flowertype and day of the week. The second block contained the variable(s) of interest, KOA in the first model, KOAINT and KOAEXT in the second model.

The reason for choosing this sequential regression approach is a theoretical one. The order in which variables are entered into the regression equation can drastically affect the interpretation of the results for individual independent variables (Tabachnick and Fidell 2001, 131-139), which can affect the correct testing of hypothesis. If the goal of this model was to simply construct the best possible model for explaining the price of flowers, a stepwise regression approach could have sufficed. In that case the individual contributions of independent variables are of less importance than when hypothesis testing is the goal of the model. Therefore, although we could have estimated the model in a single regression step, it is more appropriate to use a two-step approach with the main variable entering after all 
control variables are entered. This ensures that the added effect is uniquely due to that variable and no captured by the control variables.

Descriptive Statistics

\begin{tabular}{llrrrr}
\hline \hline & $\mathrm{N}$ & Minimum & Maximum & \multicolumn{1}{c}{ Mean } & $\begin{array}{c}\text { Std. } \\
\text { Deviation }\end{array}$ \\
\hline PRICE & 81803 & .00 & 715.00 & 173.1276 & 87.7969 \\
VBN & 81803 & 73.60 & 279.40 & 142.2774 & 41.6919 \\
DIAM & 81803 & .00 & 29.00 & 13.1417 & 2.8869 \\
LENGTH & 81803 & .00 & 45.00 & .1616 & 2.5085 \\
QUANT & 81803 & 5.00 & 2304.00 & 70.8860 & 104.4122 \\
KOA & 81803 & .00 & 1.00 & .3229 & .4676 \\
Valid N (listwise) & 81803 & & & & \\
\hline \hline
\end{tabular}

Table 1 Descriptives KOA analysis

\section{Correlations}

\begin{tabular}{|c|c|c|c|c|c|c|c|}
\hline Variables & & PRICE & VBN & DIAM & LENGTH & QUANT & $\mathrm{KOA}$ \\
\hline \multirow[t]{2}{*}{ PRICE } & Pearson Corr. & 1.000 & $.524^{\star \star}$ & $.507^{\star \star}$ & $.030^{\star *}$ & $-.232^{\star \star}$ & $-.049^{\star \star}$ \\
\hline & Sig. (2-tailed) & . & .000 & .000 & .000 & .000 & .000 \\
\hline \multirow[t]{2}{*}{ VBN } & Pearson Corr. & $.524^{\star \star}$ & 1.000 & $.022^{\star \star}$ & $.008^{\star}$ & $-.044^{\star \star}$ & $.016^{\star *}$ \\
\hline & Sig. (2-tailed) & .000 & . & .000 & .022 & .000 & .000 \\
\hline \multirow[t]{2}{*}{ DIAM } & Pearson Corr. & $.507^{\star *}$ & $.022^{\star *}$ & 1.000 & $.045^{\star *}$ & $-.219^{\star *}$ & $-.038^{\star *}$ \\
\hline & Sig. (2-tailed) & .000 & .000 & . & .000 & .000 & .000 \\
\hline \multirow[t]{2}{*}{ LENGTH } & Pearson Corr. & $.030^{* *}$ & $.008^{*}$ & $.045^{\star \star}$ & 1.000 & $-.010^{\star *}$ & $.015^{\star \star}$ \\
\hline & Sig. (2-tailed) & .000 & .022 & .000 & . & .004 & .000 \\
\hline \multirow[t]{2}{*}{ QUANT } & Pearson Corr. & $-.232^{\star *}$ & $-.044^{\star *}$ & $-.219^{\star \star}$ & $-.010^{\star \star}$ & 1.000 & $.265^{\star \star}$ \\
\hline & Sig. (2-tailed) & .000 & .000 & .000 & .004 & . & .000 \\
\hline \multirow[t]{2}{*}{$\mathrm{KOA}$} & Pearson Corr. & $-.049^{* *}$ & $.016^{\star \star}$ & $-.038^{\star \star}$ & $.015^{\star \star}$ & $.265^{\star *}$ & 1.000 \\
\hline & Sig. (2-tailed) & .000 & .000 & .000 & .000 & .000 & \\
\hline
\end{tabular}

${ }^{* \star}$. Correlation is significant at the 0.01 level (2-tailed).

*. Correlation is significant at the 0.05 level (2-tailed).

Table 2 Crosscorrelations KOA analysis

14 
Coefficients $^{\mathrm{a}}$

\begin{tabular}{|c|c|c|c|c|c|}
\hline \multirow[b]{2}{*}{ Variables } & \multicolumn{2}{|c|}{$\begin{array}{c}\text { Unstandardized } \\
\text { Coefficients }\end{array}$} & \multirow{2}{*}{$\begin{array}{c}\text { Standardi } \\
\text { zed } \\
\text { Coefficien } \\
\text { ts }\end{array}$} & \multirow[b]{2}{*}{$\mathrm{t}$} & \multirow[b]{2}{*}{ Sig. } \\
\hline & $B$ & Std. Error & & & \\
\hline Constant & -138.910 & 3.343 & & -41.551 & .000 \\
\hline VBN & 1.065 & .004 & .506 & 266.474 & .000 \\
\hline LENGTH & -.333 & .138 & -.010 & -2.412 & .016 \\
\hline DIAM & 11.084 & .075 & .364 & 148.462 & .000 \\
\hline QUANT & -.041 & .002 & -.049 & -23.555 & .000 \\
\hline TUESDAY & -4.312 & .468 & -.020 & -9.221 & .000 \\
\hline WEDNESDAY & -7.711 & .499 & -.034 & -15.462 & .000 \\
\hline THURSDAY & -6.056 & .755 & -.016 & -8.025 & .000 \\
\hline FRIDAY & -2.328 & .457 & -.011 & -5.099 & .000 \\
\hline $\mathrm{KOA}$ & -2.932 & .368 & -.016 & -7.962 & .000 \\
\hline
\end{tabular}

a. Dependent Variable: PRIJS

\section{Table 3 Regression coefficients KOA analysis}

Table 1 contains the descriptives for the first model, table 2 its cross-correlations. Table 3 shows the regression coefficients of the final model. This model had an adjusted $\mathrm{R}^{2}$ of 0.713 , which did not change when the KOA variable was added in the second block. This implies that the contribution of KOA to the overall price model is negligible. However, the tolerance statistic of 0.911 shows that the KOA variable is practically orthogonal to the other variables, which implies that its contribution is unique and not captured by all the other variables. As can be seen in table 3 , the coefficient for KOA is negative and significant, yielding support for hypothesis 1 .

Table 4 contains the results for the regression of the second model, with the KOA buyers split in internal KOA buyers (KOAINT) and external KOA buyers (KOAEXT) and it contains some surprising results. 


\section{Coefficients $^{\mathrm{a}}$}

\begin{tabular}{|c|c|c|c|c|c|}
\hline & \multicolumn{2}{|c|}{$\begin{array}{l}\text { Unstandardized } \\
\text { Coefficients }\end{array}$} & \multirow{2}{*}{$\begin{array}{c}\text { Standardi } \\
\text { zed } \\
\begin{array}{c}\text { Coefficien } \\
\text { ts }\end{array} \\
\text { Beta }\end{array}$} & \multirow[b]{2}{*}{$\mathrm{t}$} & \multirow[b]{2}{*}{ Sig. } \\
\hline & B & Std. Error & & & \\
\hline Constant & -138.595 & 3.342 & & -41.475 & .000 \\
\hline VBN & 1.064 & .004 & .505 & 266.232 & .000 \\
\hline DIAM & 11.087 & .075 & .365 & 148.571 & .000 \\
\hline LENGTH & -.338 & .138 & -.010 & -2.447 & .014 \\
\hline QUANT & -.043 & .002 & -.051 & -24.370 & .000 \\
\hline TUESDAY & -4.384 & .468 & -.021 & -9.378 & .000 \\
\hline WEDNESDAY & -7.554 & .499 & -.033 & -15.147 & .000 \\
\hline THURSDAY & -6.105 & .754 & -.016 & -8.093 & .000 \\
\hline FRIDAY & -2.333 & .456 & -.011 & -5.111 & .000 \\
\hline KOAINT & -5.182 & .445 & -.023 & -11.631 & .000 \\
\hline KOAEXT & .097 & .500 & .000 & .195 & .845 \\
\hline
\end{tabular}

a. Dependent Variable: PRIJS

\section{Table 4 Regression coefficient for KOA internal/external model}

The two important coefficients are those for KOAEXT and KOAINT. The latter was negative as expected: -5.182. However, the KOAEXT coefficient was marginally positive and not significant, indicating that external KOA buyers paid the same prices as did traditional buyers. This means that the hypothesis $2 \mathrm{a}$ is only partially validated, namely only for the internal KOA buyers. Additionally, this means that we have to reject the hypothesis $2 b$, as the internal KOA buyers actually paid less than the external KOA buyers.

\section{Discussion}

The results indicate that the first hypothesis is supported, implying that KOA-buyers do indeed pay lower prices than traditional buyers. However, when KOA-buyers are split into internal and external KOA-buyers, a somewhat different picture emerges. Although the reduced price hypothesis is supported for internal KOA buyers, the situation for external 
KOA buyers is rather more complicated. First of all, there is the fact that they do not differ significantly from traditional buyers in the auction hall (the rejection of hypothesis $2 \mathrm{a}$ ). A possible explanation for this is that perhaps the external KOA buyers use the savings in transaction costs to pay higher prices in order to increase their chances of winning the auction. One setting in which this would make sense is if they have an orderbook to fill, because then they do not want to run the risk of not being able to deliver the flowers to their customers. This may be particularly so if their customers are relatively price-insensitive.

The second surprising finding is the reversal of the expected price difference between internal and external KOA buyers. It was expected that the information disadvantage that external KOA buyers face compared to internal KOA buyers, since they were not able to physically inspect the flowers in the morning, would lead them to bid lower on average, analogous to the reasoning in Koppius et al. (1998, forthcoming). The fact that they actually pay higher prices than internal buyers is not easy to explain. Although internal KOA-buyers tend to be much larger (in terms of purchasing volume) than external KOA-buyers, it is not obvious how this could explain the difference, particularly since the volume of the transaction is accounted for in the regression model through the QUANT variable. The orderbook explanation offered above for the non-existence of the difference between external and traditional buyers might also apply here: if external KOA-buyers tend to buy more 'on order' than internal KOA buyers, they are likely to pay higher prices.

A different explanation that does not rely on unobserved variables (such as being an orderbook buyer) may have to do with the effect of reduced market state information described earlier. When discussing the hypothesis, it was mentioned that effect direction and size was unclear and therefore left unspecified, but given these results, we can possibly reassess that statement. As mentioned in paragraph 3, internal KOA-buyers had access to the video security system. This gave them information that external KOA-buyers lacked. For instance if there was an interruption in the auctioning process, internal KOA-buyers could see whether this was due to a mechanical defect or other reasons. Or, information more relevant to their bidding behavior: internal KOA-buyers could see how many people were in the auction hall. This would allow them to more accurately assess the total demand than external KOA-buyers, who only had information about the total supply. Essentially, external KOA- 
buyers have to pay a premium to cover the increased uncertainty about demand if they still want to win the auction.

\section{Conclusions}

In this paper we empirically investigated the differences in bidding behavior between traditional bidders in flowers auctions and bidders who bid from their offices using an ISDN linkup (KOA bidders). As both types of bidders participated in the exact same auctions, this allows for a detailed, direct comparison between these two categories of bidders.

The only a priori differences between the bidders are reduced transaction costs and reduced availability of market state information for the electronic bidders. This implies a reduction of transaction costs for electronic bidders, which in turn is hypothesized to lead to lower prices (Bakos 1991, 1997). The effect of the reduction in market state information was initially expected to be negligible compared to the transaction cost effect. The resulting reduced price hypothesis was tested using the transaction database of a large Dutch flower auction. The results from a regression model yield support for this hypothesis as electronic bidders do indeed pay lower prices.

The electronic bidders could be split in bidders who had an office on the auction complex itself and bid from there (internal KOA buyers) and bidders who did not have such an office and therefore bid from their offices outside the auction complex (external KOA buyers). The internal KOA buyers had an information advantage on product quality, because they could inspect the flowers in the auction warehouse before the auction started and they had access to the security camera system, which in particular gave them some extra information about the number of bidders present. External KOA buyers lacked this extra market state information. A second model was constructed to investigate the differences between these two categories, where external KOA-buyers were expected to pay a lower price (as in the first model, the effects of reduced market state information were expected to be negligible to the main effect of product quality information). Results from this second regression model indicate that the reduced price effects found in the first model are due only to the internal KOA buyers. External KOA buyers pay the same prices as traditional buyers in the auction hall. This 
implies that the benefits of lower transaction costs for external KOA buyers do not show up in the prices they pay and the information disadvantage they have compared to internal KOA buyers is of no consequence either. This runs counter to initial theoretical predictions. A possible explanation could be bidder heterogeneity: perhaps external KOA buyers, more so than internal KOA buyers, tend to buy 'on order'. If buyers have an orderbook to fill for their customers and they do not want to run the risk of having to sell 'no', they can be expected to be less price-sensitive, particularly if their customers are not very price-sensitive either. This could result in higher prices being paid by orderbook buyers, in this case the external KOA buyers.

Another explanation is that the market state information mattered much more than expected: because external KOA-buyers cannot see the number of bidders in the auction hall, they cannot assess total demand as accurately as internal KOA-buyers and therefore they have to pay a bid premium to account for this increased uncertainty of being able to win the auction. Further research is obviously needed, but it seems safe to say that the effects of reduced transaction costs are not as straightforward as current theory suggests, particularly when the effects of product quality information and market state information are taken into account. This paper also suggests information itself is a multidimensional construct: different types of information (market state information versus product quality information) have different effects. Aggregating those into a single dimension of information may obscure important underlying regularities.

\section{REFERENCES}

Akerlof, G. A. (1970). The market for 'lemons': Quality uncertainty and the market mechanism. Quarterly Journal of Economics, 84(August), 488-500.

Bailey, J. P. (1998). Electronic commerce: Prices and consumer issues for three products: Books, compact dics and software. OECD Observer(4).

Bakos, J. Y. (1991). A strategic analysis of electronic marketplaces. MIS Quarterly, 295-310.

Bakos, J. Y. (1997). Reducing buyer search costs: implications for electronic marketplaces. Management Science, 43(12), 1676-1692. 
Brynjolfsson, E., \& Smith, M. D. (2000). Frictionless commerce? A comparison of Internet and conventional retailers. Management Science, 46(4), 563-585.

Chen, P.-Y., \& Hitt, L. (2001). Switching costs in electronic markets: The case of online retail brokers (Working paper ). Philadelphia, PA, USA: The Wharton School.

Clemons, E. K., Hann, I.-H., \& L.Hitt. (2000). The nature of competition in electronic markets: An investigation of online travel agent offerings (Working paper ). Philadelphia, PA, USA: The Wharton School.

Coase, R. (1937). The nature of the firm. Economica, 4, 386-405.

Coval, J. and T. Shumway (2000). Is sound just noise?. University of Michigan working paper, Ann Arbor, MI, USA.

Degeratu, A. M., Rangaswamy, A., \& Wu, J. N. (2000). Consumer choice behavior in online and traditional supermarkets: The effects of brand name, price, and other search attributes. International Journal of Research in Marketing, 17(1), 55-78.

Kambil, A., \& van Heck, E. (1998). Reengineering the Dutch Flower Auctions: A Framework for Analyzing Exchange Organizations. Information Systems Research, 9(1), 1-19.

Koppius, O.R., E. Van Heck and M.J.J. Wolters (1998), "Product representation and price formation in screen auctions: empirical results from a Dutch flower auction", Proceedings of the First International Conference on Telecommunications and Electronic Commerce, ICTEC'98, Nashville, TN, USA.

Koppius, O.R., E. van Heck \& M.J.J. Wolters, (forthcoming) "The importance of product representation online: empirical results and implications for electronic markets", conditionally accepted at Decision Support Systems.

Lee, H. G., \& Clark, T. H. (1997). Market process reengineering through electronic market systems: Opportunities and challenges. Journal of Management Information Systems, 13(3), 113-137.

Lee, H. G. (1998). Do electronic marketplaces lower the price of goods? Communications of the Acm, 4l(1), 73-80.

Lee, H. G., Westland, J. C., \& S.Hong. (1999). The impact of electronic markets on product prices: An empirical study of AUCNET. International Journal of Electronic Commerce, 4(2-Winter), 45-60. 
Lynch, J. G., \& Ariely, D. (2000). Wine online: Search costs affect competition on price, quality, and distribution. Marketing Science, 19(1), 83-103.

Malone, T. W., Yates, J., \& Benjamin, R. (1987). Electronic markets and electronic hierarchies. Communication of the ACM, 30(6), 484-497.

McAfee, R. P., \& McMillan, J. (1987). Auctions and bidding. Journal of Economic Literature, 25, 699-738.

Sinha, I. (2000). Cost transparency: the net's real threat to prices and brands. Harvard Business Review, 78(2), 43-50.

Smith, M. D., Bailey, J., \& Brynjolfsson, E. (1999). Understanding digital markets: review and assessment (Working Paper ). Boston, MA: MIT Sloan School.

Tabachnick, B. G., and Fidell, L. S. (2001). Using Multivariate Statistics , 4th ed. Boston: Allyn and Bacon. 


\section{Publications in the Report Series Research* in Management}

ERIM Research Program: "Business Processes, Logistics and Information Systems"

\section{2}

The importance of sociality for understanding knowledge sharing processes in organizational contexts Niels-Ingvar Boer, Peter J. van Baalen \& Kuldeep Kumar ERS-2002-05-LIS

Crew Rostering for the High Speed Train

Ramon M. Lentink, Michiel A. Odijk \& Erwin van Rijn

ERS-2002-07-LIS

Equivalent Results in Minimax Theory

J.B.G. Frenk, G. Kassay \& J. Kolumbán

ERS-2002-08-LIS

An Introduction to Paradigm

Saskia C. van der Made-Potuijt \& Arie de Bruin

ERS-2002-09-LIS

Airline Revenue Management: An Overview of OR Techniques 1982-2001

Kevin Pak \& Nanda Piersma

ERS-2002-12-LIS

Quick Response Practices at the Warehouse of Ankor

R. Dekker, M.B.M. de Koster, H. Van Kalleveen \& K.J. Roodbergen

ERS-2002-19-LIS

Harnessing Intellectual Resources in a Collaborative Context to create value

Sajda Qureshi, Vlatka Hlupic, Gert-Jan de Vreede, Robert O. Briggs \& Jay Nunamaker

ERS-2002-28-LIS

Version Spaces and Generalized Monotone Boolean Functions

Jan C. Bioch \& Toshihide Ibaraki

ERS-2002-34-LIS

Periodic Review, Push Inventory Policies for Remanufacturing

B. Mahadevan, David F. Pyke, Moritz Fleischman

ERS-2002-35-LIS

Modular Decomposition of Boolean Functions

Jan C. Bioch

ERS-2002-37-LIS

Classification Trees for Problems with Monotonicity Constraints

R. Potharst \& A.J. Feelders

ERS-2002-45-LIS

A complete overview of the ERIM Report Series Research in Management: http://www.ers.erim.eur.nl

ERIM Research Programs:

LIS Business Processes, Logistics and Information Systems

ORG Organizing for Performance

MKT Marketing

F\&A Finance and Accounting

STR Strategy and Entrepreneurship 
Allocation of Railway Rolling Stock for Passenger Trains

Erwin Abbink, Bianca van den Berg, Leo Kroon \& Marc Salomon

ERS-2002-47-LIS

Monotone Decision Trees and Noisy Data

Jan C. Bioch and Viara Popova

ERS-2002-53-LIS

Business Modeling Framework For Personalization In Mobile Business Services: a Case and Sociological Analysis L-F Pau, Jeroen Dits

ERS-2002-56-LIS

Polynomial time algorithms for some multi-level lot-sizing problems with production capacities

Stan van Hoesel, H. Edwin Romeijn, Dolores Romero Morales, Albert P.M. Wagelmans

ERS-2002-59-LIS

A Note on Ending Inventory Valuation in Multiperiod Production Scheduling

Wilco van den Heuvel, Alfred P.M. Wagelmans

ERS-2002-63-LIS

Determining The Optimal Order Picking Batch Size In Single Aisle Warehouses

Tho Le-Duc and René B.M. de Koster

ERS-2002-64-LIS

Solving Variational Inequalities Defined on A Domain with Infinitely Many Linear Constraints

Shu-Cherng Fang, Soonyi Wu, Ş. İlker Birbil

ERS-2002-70-LIS

Entropic Regularization Approach for Mathematical Programs with Equilibrium Constraints

Ş. İlker Birbil, Shu-Cherng Fang, Jiye Han

ERS-2002-71-LIS

On the Finite Termination of An Entropy Function Based Smoothing Newton Method for Vertical Linear Complementarity Problems

Shu-Cherng Fang, Jiye Han, Zhenghai Huang, Ş. İlker Birbil

ERS-2002-72-LIS

The Role Of Product Quality Information, Market State Information And Transaction Costs In Electronic Auctions Otto Koppius and Eric van Heck

ERS-2002-73-LIS 